\title{
PHOTOELECTROCHEMICAL INVESTIGATIONS OF THERMALLY FORMED FILMS ON TITANIUM SURFACES
}

\author{
Irena Mickova \\ "SS. Cyril and Methodius" University of Skopje, Faculty of Technology and Metallurgy, \\ P.O. Box 80, MK-1001 Skopje, Republic of Macedonia \\ mickova@tmf.ukim.edu.mk
}

\begin{abstract}
The semi-conducting and photoelectrical properties of $\mathrm{TiO}_{2}$ films prepared with thermal oxidation of titanium in the temperature range from 200 to $600{ }^{\circ} \mathrm{C}$ were studied. Short theoretical background for application of photocurrent in semiconductor electrochemistry was presented. For all investigated temperatures and times of thermal treatments the semi-conducting properties as photocurrent peaks and band gap energies were determined. At lower temperatures the anodic values of photocurrent peaks confirmed the existence of $n$-type semiconducting $\mathrm{TiO}_{2}$ films with amorphous structure. With increasing the temperature and time of thermal treatment the development of crystalline structure in the film is followed with small decreasing of band gap energy. For films formed at higher temperatures and longer time of thermal treatment the determined band gap energies are close to the $3 \mathrm{eV}$ that corresponds to the rutile structure of the film.
\end{abstract}

Key words: $\mathrm{TiO}_{2}$ films; semiconductor; photocurrent; rutile structure

\section{ФОТОЕЛЕКТРОХЕМИСКИ ИСТРАЖУВАҢА НА ФИЛМОВИ ТЕРМИЧКИ ФОРМИРАНИ ВРЗ ТИТАНОВИ ПОВРШИНИ}

\begin{abstract}
Полуспроводничките и фотоелектрохемиските својства на $\mathrm{TiO}_{2}$-филмови приготвувани со термичка оксидација на титан се истражувани во температурно подрачје од 200 до $600{ }^{\circ} \mathrm{C}$. Даден е краток теоретски осврт на примената на фотострујата во електрохемијата на полуспроводници. За сите испитувани температури и време траење на термичкиот третман се определувани полуспроводничките својства како што се фотострујните пикови и енергијата на забранетите зони. При пониски температури регистрираните анодни вредности на фотострујните пикови го потврдија постоењето на $n$-тип полуспроводнички $\mathrm{TiO}_{2}$-филм со аморфна структура. Со зголемувањето на температурата и времето на термичкиот третман развивањето на кристалната структура во филмот е следено преку намалување на вредностите на енергијата на забранетите зони. За филмови формирани при повисоки температури и подолги времиња на термички третман определените енергии на забранетата зона се блиски до вредностите од $3 \mathrm{eV}$, што одговара на рутилна структура на филмот.
\end{abstract}

Клучни зборови: $\mathrm{TiO}_{2}$ филмови; полуспроводник; фотоструја; рутилна структура

\section{INTRODUCTION}

The photo-effect in electrochemical systems was recognized in 1839 by the French scientist Becquerel [1]. He discovered that an additional current could be obtained from the metal electrodes covered with oxide film by light irradiation. At that time, this phenomenon was named Becquerel effect.
The application of the photo-effect for solar energy conversion into electrical and/or chemical energy has undergone an enormous advancement during the last 50 years, especially with development of semi-conducting materials [2-6]. At the present, three basic methods that can convert the light (generally Sun light) into useful energy exist: (a) Photosynthesis - the natural processes of solar energy illumination involving conversion of $\mathrm{CO}_{2}$ 
and $\mathrm{H}_{2} \mathrm{O}$ to sugars and oxygen, (b) Photovoltaic cells - which can convert solar illumination into electrical energy, and (c) Photo-electrochemical cells - where photo-electrochemical processes are utilized for the conversion of light into electrical and/or chemical energy.

The photo-electrochemical cell (Fig. 1) consists of two electrodes: one semi-conducting under illumination and one metal electrode, as a counter electrode, both immersed in electrolyte containing electro-active redox species $\mathrm{A} / \mathrm{A}^{-}$.

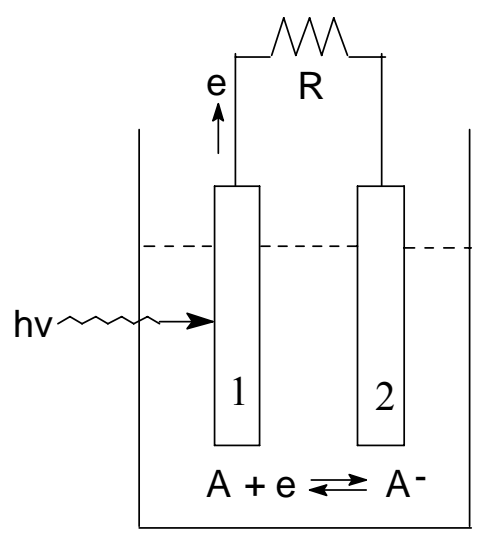

Fig. 1. Photoelectrochemical cell:

1 - semiconducting electrode, 2 - metal counter electrode

The semi-conducting electrode should efficiently absorb incidence light, creating delocalized charges and producing an electrical current, while the interface between the semiconductor and the liquid is responsible for electrochemical reactions that lead to energy conversion. In operational conditions the photo-electrochemical cell can produce electricity, chemical fuels or both. The overall process that occurs in the photo-electrochemical cell depends only on the electrochemical reactions on the semi-conducting and metallic counter electrode. In the case of the reactions at the counter electrode are reversible of those at semi-conducting electrode, no net chemical change will take place in the cell. The light induced will only produce electrical current. Alternatively, if sufficient energy is available from the delocalized electrons, the water electrolysis producing $\mathrm{O}_{2}$ and $\mathrm{H}_{2}$ as fuels from the incident photon energy might be possible. The energy storage processes in photo-electrochemical cells result from mobility of the charge carriers that are created by light excitation. The ability for transport of charge carriers will depend critically on the electronic properties of the semiconducting electrode. By introducing the doping atoms as impurity or existing crystal defects in very low concentrations (1 part per billion) the conductivity of semi-conductor samples will drastically increase. Doping atoms can be either donors or acceptors. Donors produce an electron in the conduction band and a positive charge on the doping atom. They create free electrons and the sample is denoted as a $n$-type semiconductor. Acceptors produce holes in the valence band and negative charges on the doping atom. They create holes, which have a positive charge and the sample is denoted as a p-type semiconductor. Electrons are majority carriers in the $n$-type semiconductor and holes are the majority carriers in the $p$-type semiconductor.

On Fig. 2 the schematic presentation of energy levels in the semiconductor with donors and acceptors doping atoms, in reference with the bend edges is shown.

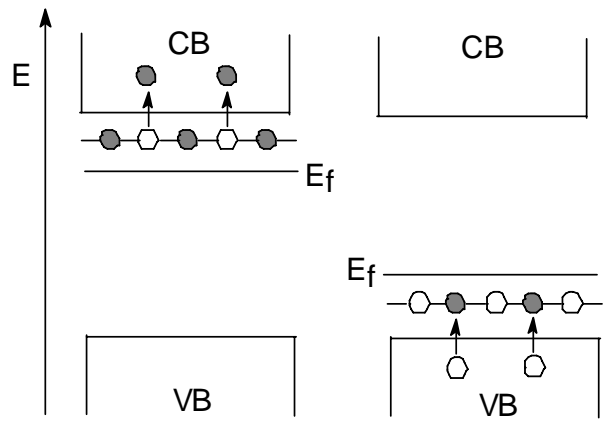

Fig. 2. Schematic presentation of band energies to semiconductors; (a) $n$-type semiconductor, (b) $p$-type semiconductor, 1 - valence band, 2 - conduction band, 3 - donors level, 4 - acceptors level, Ef - Fermi level, $\mathrm{O}_{\text {- electrons, }} \mathrm{O}_{- \text {holes }}$

In comparison with undoped intrinsic semiconductors (pure semiconductors), where the Fermi level at the temperature of $0 \mathrm{~K}$ is located in the middle of the forbidden zone, for doped semiconductors this level is shifted to the conduction band where donors are close to the conduction band, or to the valence band where acceptors are close to the valence band.

Titanium dioxide is an important semiconductor in photo-electrochemical applications as: photocatalysts for water treatment, dye sensitized, conjugated polymers, inorganic semiconductor for solar cell applications etc. [7-9]. It occurs in three mineral forms: rutile, anatase and brookite. But only two of them: rutile and anatase, are used in the photo-electrochemical research. The rutile 
structure can be obtained by thermal oxidation of the titanium base metal [10] and anatase structure, electrochemically by anodic oxidation of $\mathrm{Ti}$ electrodes in various electrolytes [11]. So far more attempts were consecrated to the formation of passive films with the amorphous and anatase structure $[12,13]$. The electronic structure of these films was investigated by photocurrent measurements (using continuous monochromatic lights and pulsed laser irradiations). Very often these measurements were combined with capacitance measurements [14, 15]. Relatively less photocurrent data can be found for the thermally obtained rutile structure.

In this work more systematic photocurrent measurements are consecrated to the thermally films with the rutile structure, formed on the $\mathrm{Ti}$ electrode for various temperatures and time of thermal treatments. From these measurements some semiconducting properties such as the type of semiconductor and the band gap energies ware determined.

\section{EXPERIMENTAL}

Preparation of samples. Ti discs were prepared by cutting the titanium rod (Alfa Aesar, a Johnson Mathey Company) with purity of $99.8 \%$ and a diameter of $6.35 \mathrm{~mm}$. Before the thermal treatment one basis of each disc, with approximately height of $2-3 \mathrm{~mm}$, was successively mechanically polished with emery papers $(1000,4000$ and 5000) and diamond sprays up to $0.1 \mu \mathrm{m}$ to yield a mirror like surface. After mechanical polishing the discs were ultrasonically cleaned in ethanol and finally dried by the compressed air.

Heating procedure. The heating treatment of well mechanical polished discs (showing mirror brightness) was performed in a tubular oven with previously adjusted constant temperature. The low temperature limit was $200{ }^{\circ} \mathrm{C}$ because between the room temperature and $200{ }^{\circ} \mathrm{C}$ not significant photocurrent change was observed. The upper temperature limit was $600{ }^{\circ} \mathrm{C}$. At this temperature the diffusion of oxygen into the bulk of the substrate becomes a rate limiting process and the development of fast film inhomogeneity begins. During the input of the discs into the oven the temperature inside of the oven decreased for about $2{ }^{\circ} \mathrm{C}$. But it will reach the previous constant value for about 3 min. The small deviation of the temperature re- gime did not significantly influence the formed film thickness that was approved by ellipsometric measurements [10]. The heating time for each temperature of investigation was raging from 1 min to $30 \mathrm{~min}$. After the heating treatments, the discs were removed from the oven and immediately placed in the vacuum desiccator. For the relatively short time their temperatures were equilibrated to the room temperature. The photocurrent measurements for each temperature and oxidation time were repeated at least three times. After finishing the measurements the oxide film from each sample was removed by mechanical re-polishing, using only diamond sprays, that was a satisfactory procedure in order to reuse the same samples for the next oxidation.

Apparatus. The photocurrent measurements were carried out with the combined electrochemi$\mathrm{cal} /$ photochemical system consisting of a photoelectrochemical cell, a potentiostat/galvanostat (HEKA 488) interfaced with PC, a xenon lamp $500 \mathrm{~W}$, a monochromator (McPherson GM252), a chopper (EG\&G model $125 \mathrm{~A}$ ), a two phase lockin amplifier (PAR 2308) and a register (Fig. 3).

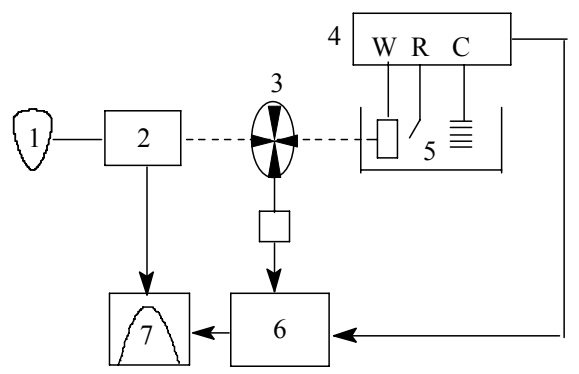

Fig. 3. Experimental set-up for photocurrent measurements: 1 - light source, 2 - monochromator, 3 - chopper, 4 - potentiostat, 5 - photo-electrolytic cell, 6 - lock-in amplifier, 7 - register

The Ti discs were fixed in a classical electrochemical cell built from quartz (for simultaneously electrochemical and photocurrent measurements). The discs were adjusted in a teflon holder and positioned to a light source in order to obtain maximum photocurrent response. The used electrolyte was $1 \mathrm{M} \mathrm{H}_{2} \mathrm{SO}_{4}$ prepared from concentrated $\mathrm{H}_{2} \mathrm{SO}_{4}$ (p.a. Merck) in triply distilled and de-ionized water. The counter electrode was a large surface Pt grid while the reference electrode was a saturated calomel electrode. The lock-in amplifier was used to measure the amplitude and the phase of signals buried in noise. 
Measuring procedure. By illumination of the semi-conducting electrode (Fig. 3) with the light energy greater, or equal to the band energy gap, the absorption of photons generated charge carriers. With potentiostatically polarization of this electrode, the formed band bending causes migration the charge carriers and appearance of measurable photocurrent. For $p$-type semiconductors the electron migrates to the surface from where it can react with an unoccupied (acceptor) state in the electrolyte which is represented by oxidized chemical species. The hole flows to the backside contact and the resulting current is cathodic. For the ntype semiconductor the hole migrates to the surface reacting with an occupied (donor) state, while the electron moves to the backside contact and the resulting current is anodic.

During the illumination of the semi-conducting electrode the light was chopped into $10 \mathrm{~Hz}$ pulses by a rotating blade in a chopper. Generally in photocurrent measurements the light beam was chopped to provide light pulses to the semiconducting working electrode in order to create an AC input signal in the lock-in amplifier. The chopped light allowed the determination of dark current and photocurrent in a single polarization curve. A monochromator is used to select the desired wavelength of light, generally in the range from $200 \mathrm{~nm}$ to $420 \mathrm{~nm}$. By chopping the light the created currents on the semi-conducting electrode under dark and illuminated conditions represent the AC input signal to the lock-in amplifier. To recognize the signal of interest it must be compared with some reference signal of the same frequency. During the photocurrent measurements, the reference signal is dark current (chopper positions when the semiconductor electrode is not illuminated) locked in lock-in the amplifier. The output is DC photocurrent from light absorption (chopper positions when the semi-conducting electrode is illuminated), as an offset from dark current which is adjusted to zero position (Fig. 4).

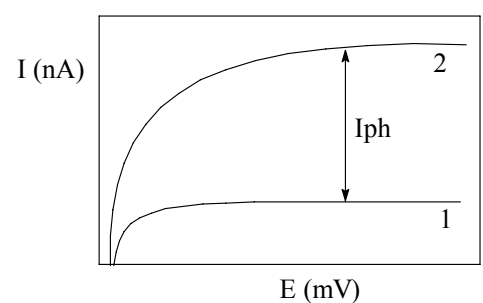

Fig. 4. The current - voltage behavior of semi-conducting electrode in contact with electrolytic solution.

1 - in the dark, 2 - under illumination

$$
I_{p h}=I-I_{d}
$$

In that way the measured photocurrents are referred to the dark current and can directly read from the lock-in amplifier.

\section{RESULT AND DISCUSSION}

Thermal oxidation of Ti often is used to increase oxide thickness and corrosion resistance of the base metal for extending the service life. So far investigations in our laboratory reported that $\mathrm{Ti}$ oxide films formed by thermal oxidation have superior corrosion resistance over the oxide film formed by anodizing $[10,16]$.

The recent literature data are more consecrated to photoelectrochemical activity of the $\mathrm{TiO}_{2}$ particles prepared by the sol-gel method and thermally simulated current by structural transformation of amorphous to anatase phase in the film [17]. The particulate prepared layers from dispersion of Degussa P-25 $\mathrm{TiO}_{2}$ deposited onto the $\mathrm{Ti}$ substrate and subsequently sintered from $500{ }^{\circ} \mathrm{C}$ to $700{ }^{\circ} \mathrm{C}$ have been also practiced $[18,19]$. The photocurrent measured values for particulate $\mathrm{TiO}_{2}$ layers are much lower than those of thermal layers, due to the poor contact among individual particles, resulting in high electric resistance of the whole layer. Oppositely, the thermal layers of $\mathrm{TiO}_{2}$ formed on the Ti substrate have very good mechanical properties due to good adhesion. The special advantage of the $\mathrm{TiO}_{2}$ layer grown thermally on $\mathrm{Ti}$ is the supports of high electronic conductivity. This is the main reason why our measurements are consecrated to the thermally grown of $\mathrm{TiO}_{2}$ layers.

On Fig. 5 the photocurrent spectra of Ti films formed for three different temperatures of thermal treatment are given. For clarity, the spectra recorded on 300 and $500{ }^{\circ} \mathrm{C}$ are omitted. It should be mentioned that the interface $\mathrm{TiO}_{2}$ film/electrolyte is a very stable system showing well defined, reproducible and stable values of photocurrent in the order of microamperes, compared with systems where photocurrents are only in the order of nanoamperes, or even pikoamperes (in the case of particulate layers, passive films on hafnium or polymer coatings) [18-20].

The measured photocurrent essentially depends on the incident lights energy, so as a frequency of radiation increases, the measured photo- 
current increases. If the light energy $h v$ is equal or bigger than the band gap energy $E_{\mathrm{g}}$ of the semiconducting film, then a direct excitation of electrons from the valence band to the conduction band could be expected. As it can be seen from Fig. 5 the photocurrent increases with temperature as a result of increasing the film thickness.

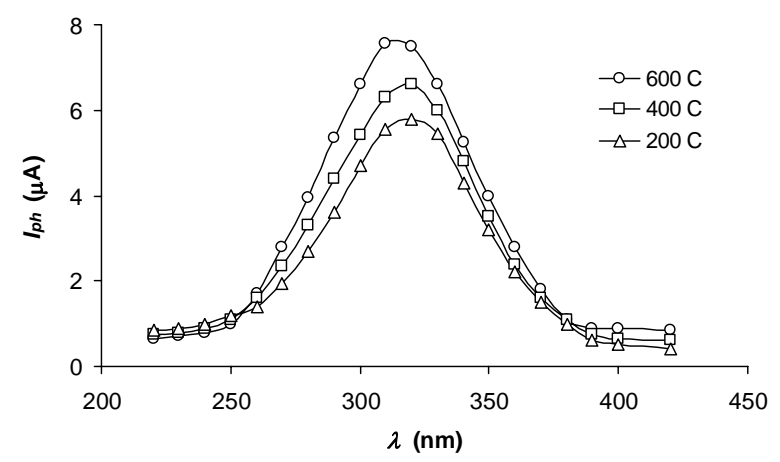

Fig. 5. Photocurrent spectra of thermally formed films on Ti surface during $30 \mathrm{~min}$. The spectra were recorded in $1 \mathrm{M} \mathrm{H}_{2} \mathrm{SO}_{4}$ at applied potential of $1,5 \mathrm{~V}$ sce

The absorbed radiation in the film is given by Lambert Beer's law. For the bulk semiconducting electrode the thickness is large enough to absorb all incidents radiation. For very thin films with not too high absorption coefficient, the photocurrent becomes proportional to the absorption coefficient and for lower wavelengths of incidence radiation the absorption is complete. For finite metal oxide film thickness the existing electrical field could be described with an optical model which takes into account multiple internal reflections. As the incident light traverses the metal oxide layer on its first pass, it is partially reflected at the metal/metal-oxide interface. When the reflected light reaches the metal-oxide electrolyte interface, it will once again be partially reflected back into the film and the whole process repeats. This manifestation of the optical process is the dependence of the photocurrent on film thickness. For a very thin film the absorption is not too strong and the reflected light can have a significant effect on the photocurrent. In our case the thermally formed film for the lowest temperature at $200{ }^{\circ} \mathrm{C}$ is enough thick, about $8 \mathrm{~nm}$ [10], so that the effect of the reflected light does not influence significantly the photocurrent values.

The value of photocurrent depends also from the value of applied potential on the working semiconducting electrode. Generally, for higher applied potentials the higher values of photocurrent are measured. In all our measurements the constant value of potential, $1.5 \mathrm{~V}$ (SCE), (for bands bending) in the solution of $1 \mathrm{M} \mathrm{H}_{2} \mathrm{SO}_{4}$ was applied.

For thinner $\mathrm{TiO}_{2}$ films, formed at lower temperature, the amorphous structure is confirmed and as an effect of the long-range disorder the strong decrease of the carrier's mobility is essentially due. It has been presented by many authors that the donor density changes with oxide film thickness $[8,14,19]$. The donor density of $n$-type semiconductive $\mathrm{TiO}_{2}$ also depends on the growth rate for oxide formation and the donor density decreases with increase of the film thickness. The film thickness is accompanied by a color changing from light yellow at $200{ }^{\circ} \mathrm{C}$, to orange at $300{ }^{\circ} \mathrm{C}$, light purple at $400^{\circ} \mathrm{C}$, purple at $500{ }^{\circ} \mathrm{C}$ and finally to bleu at $600{ }^{\circ} \mathrm{C}$. The changing of colors depends also from the time of thermal treatment. At $600{ }^{\circ} \mathrm{C}$ the film inhomogeneity begins to develop visibly.

For a lower temperature range at $200{ }^{\circ} \mathrm{C}$ and $300{ }^{\circ} \mathrm{C}$ the kinetic law of film thickness growth is logarithmic. At $400{ }^{\circ} \mathrm{C}$ the transition from logarithmic to parabolic law occurs. For temperature of $500{ }^{\circ} \mathrm{C}$ and $600{ }^{\circ} \mathrm{C}$ the film thickness growth follow the parabolic law [10].

From photocurrent spectra on Fig. 5 the band gap energy in $\mathrm{TiO}_{2}$ semi-conducting films for each temperature of thermal treatment can be calculated. Semiconductors that display a fully allowed transition between the valence band and the conduction band referred to as direct band gap semiconductors. In these materials the absorption coefficients are large and the light is strongly absorbed to the surface of the solid. Indirect band gap semiconductors generally display small absorption coefficients for photons near the band gap energy and the lowest energy electronic transition is forbidden [4]. The minimum energy required for indirect transitions can be evaluated from $\left(I_{\mathrm{ph}} h v\right)^{1 / 2}$ versus $h v$ plots. The direct transition can be evaluated from $\left(I_{p h} h v\right)^{2}$ versus $h v$ plots $[4,21]$.

Taking into account that indirect transition, having relatively small absorption coefficient is present in $\mathrm{TiO}_{2}$ semi-conducting films, the minimum energy required can be evaluated by the abscise axis intercept of the linear plots from Fig. 6 .

As it can be seen from Fig. 6, for all measured temperature the band gap energy is located close to the $3 \mathrm{eV}$, that corresponds to the band gap energy for rutile structure. The band gap energy for $\mathrm{TiO}_{2}$ amorphous is $3.1 \mathrm{eV}$ and for anatase forms $3.3 \mathrm{eV}$. 


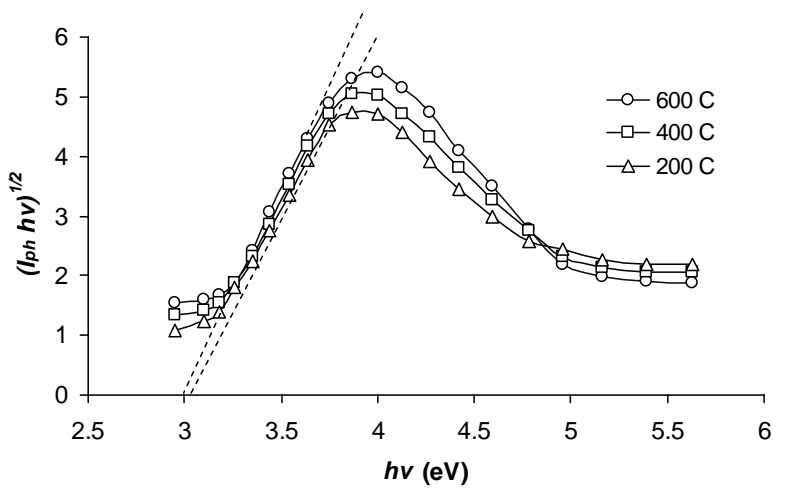

Fig. 6. Determination of optical band gap energy from the spectra on Fig. 5

Most of authors agree that the indirect band gap for rutile is $3 \mathrm{eV}[24,26]$. But yet there is disagreement what kind of oxide is present on Ti surface for the different surface pre-treatment. It is well known that after preparation of freshly Ti surfaces in atmospheric conditions instantaneously native oxide films are formed which develop slowly their thickness with time. This film in reality represents the thermally formation of the oxide film at room temperature. The previous ellipsometric measurements in our and other laboratories have shown that the film thickness can reach the values from 2-4 nm, depending on the kind of preparation of the metal surfaces (mechanical polishing, electrochemical polishing or chemical polishing) $[9,16,21,22]$. The structure of native oxide films was investigated by A. Hugot Le-Goff using Raman spectroscopy measurements with interference enhancement [23]. These investigations give the rice to patterns of the dense modification of $\mathrm{TiO}_{2}$, namely rutile. For thinner $\mathrm{TiO}_{2}$ films grown by potentiostatic ramping of the $\mathrm{Ti}$ substrate, M. Kozlowski et al. using a photoelectrochemical spectroscopy and electron diffraction have shown that the rutile is the only identifiable phase [24]. Oppositely, by the Raman spectroscopy and the X-ray diffraction Arsov et al. have reported existence of anatase for thicker anodic films and only the rutile structure for thermally formed films [10, 13]. The brookite structure can appear only during the short polarization of the Ti electrode at higher voltage when the very strong electrical field in the interface metal substrate/oxide film/electrolyte provokes electrical spark [25].

Taking into account that the thickness and colors of thermally formed films strongly depend on heating time, for each temperature of film for- mation the photocurrent spectra are measured for various times of the thermal treatment: from $1 \mathrm{~min}$ to $30 \mathrm{~min}$. On Fig. 7 the photocurrent spectra for various times of the thermal treatment are given only for the highest temperature of $\mathrm{TiO}_{2}$ at $600{ }^{\circ} \mathrm{C}$.

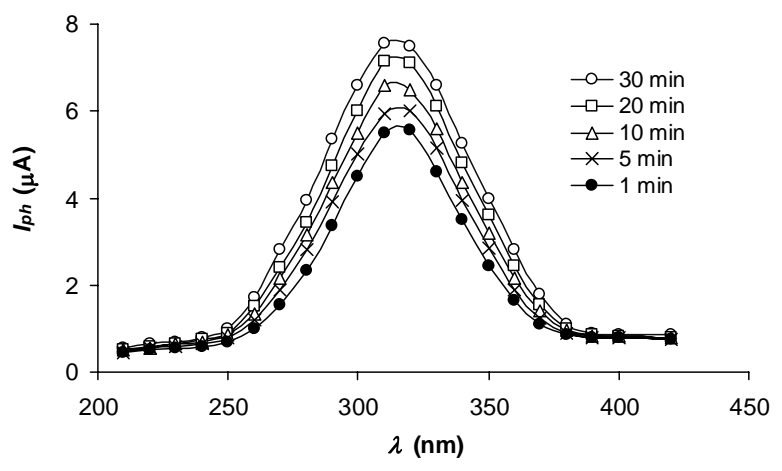

Fig. 7. Photocurrent spectra of thermally formed films at $600{ }^{\circ} \mathrm{C}$ on Ti surface during $30 \mathrm{~min}$. The spectra were recorded in $1 \mathrm{M} \mathrm{H}_{2} \mathrm{SO}_{4}$ at applied potential of $1,5 \mathrm{~V}$ sce

The deviation of photocurrent peaks position is negligible with the time of the thermal treatment. This can be explained by complete transition of amorphous film to stable crystal structure at $600{ }^{\circ} \mathrm{C}$.

By $\left(I_{p h} h v\right)^{1 / 2}$ plots versus $h v$ of the photocurrents from Fig.7 the band gap energy for each investigated time of film formation is determined, Fig. 8.

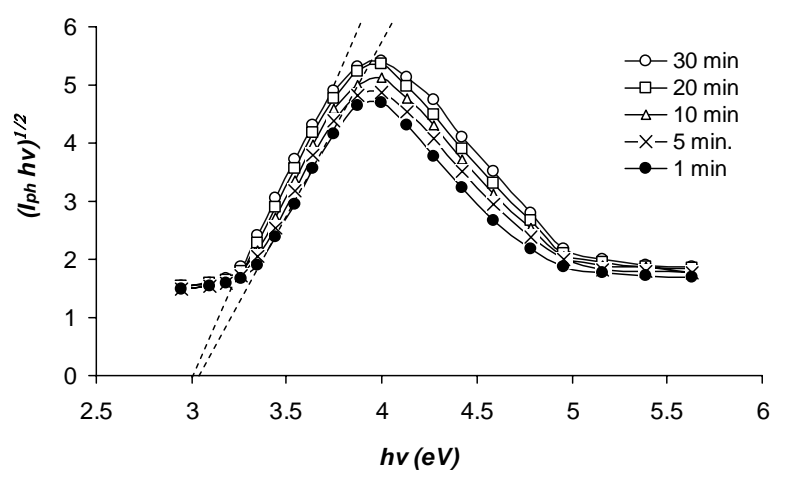

Fig. 8. Determination of optical band gap energy from the spectra on Fig. 7

As it can be seen from Fig. 8 it is evident that the band gap energy is close to $3 \mathrm{eV}$ indicating existence of the rutile form.

On Table 1 the semi-conducting parameters of $\mathrm{TiO}_{2}$ films thermally formed in the temperature range from 200 to $600{ }^{\circ} \mathrm{C}$ and time of thermal treatment of $30 \mathrm{~min}$ are summarized. 
Table 1

Semiconducting parameters of thermally formed films from $\mathrm{TiO}_{2}$ on Ti parent metal

\begin{tabular}{cccc}
\hline \hline$T\left({ }^{\circ} \mathrm{C}\right)$ & $I_{p h}(\mu \mathrm{A})$ & $\lambda(\mathrm{nm})$ & $E_{b g}(\mathrm{eV})$ \\
\hline 200 & 5.8 & 322 & 3.09 \\
300 & 6.2 & 320 & 3.06 \\
400 & 6.6 & 318 & 3.03 \\
500 & 7.1 & 315 & 3.00 \\
600 & 7.55 & 313 & 2.95 \\
\hline \hline
\end{tabular}

With rising the temperature rise the values of photocurrent peaks and the position of peaks move toward a higher wave number, or smaller energy of illumination. The band gaps energy decreased indicating augmentation of film conductivity. For higher temperatures in formed films surface defects and surface inhomogeneity begin to develop. All these parameters strongly influenced the film conductivity causing the presence of $\mathrm{Ti}$ ions and large porosity. The enhanced migration of interstitial Ti ions to the oxide film solution interface under anodic bias will result in a decrease of the donor density at the depletion layer in the oxide film. On the other hand, the increasing oxide layer thickness will influence the greater absorption of UV photons and hence increase concentration of trapped photo-generated electrons.

\section{CONCLUSION}

For all investigated $\mathrm{TiO}_{2}$ films formed in the temperature range from 200 to $600{ }^{\circ} \mathrm{C}$ and time of thermal treatments from $1 \mathrm{~min}$ to $30 \mathrm{~min}$ the photocurrent measurements have shown existence of well stable films with small deviations on the position of photocurrent peaks and values of photocurrent peaks in $\mu \mathrm{A}$ order. As a result of increasing the film thickness the values of photocurrent peaks rise with the temperature and time of thermal treatments. The determined band gap energies for all investigated films are close to the value of $3 \mathrm{eV}$, confirming existence of the rutile structure. Finally it can be concluded that the thermally formed $\mathrm{TiO}_{2}$ films with band gap energies close to the $3 \mathrm{eV}$ are not very suitable for solar energy conversion. They have to enlarge the band gaps to be efficient absorbers. But in recent time
$\mathrm{TiO}_{2}$ has been exploited to photo-catalytically oxidize organic and inorganic compounds for synthetic and waste pre-treatment applications.

Acknowledgements: The photocurrent experiments were carried out in the Institute for Physical Chemistry and Electrochemistry, Technical University in Dresden (Germany). The author acknowledges to Dr Niels Hebestreit for helpful discussions and to the Ministry of Science and Education of the Republic of Macedonia for financial support.

\section{REFERENCES}

[1] E. Becquerel - C. R. Acad. Sci. Paris, 9561 (1839).

[2] A. Heller (editor), Semiconductor Liquid-Junction Solar Cells, The Electrochemical Society Princeton, New Jersey (1977).

[3] J. Radosavljević, T. Pavlović, M. Lambić, Solarna energetika i održivi razvoj, Gradjevinska knjiga, Beograd (2004).

[4] R. Memming, Semiconductor Electrochemistry, WileyVCH Verlag GmbH (2001).

[5] A. Bard, M. Stratmann, P. Licht (editors), Semiconductor Electrochemistry and Photoelectrochemistry, Wiley-VCH Verlag GmbH. Vol. 6 (2002).

[6] I. Mickova, A. Prusi, Lj. Arsov, Electrochemical formation of semi-conducting oxides for solar energy conversion, Proceedings of the 3-rd WSEAS Int. Conf. on Energy, Environment \& Sustainable Development, 205-209 (2007) Crete, Greece.

[7] R. Breckenridge, W. Hosler, Electrical properties of titanium dioxide semiconductors, Physical Review, 91 (4), 793-802 (1953).

[8] H. R. Sprunken, R. Schumacker, R. N. Schindler, Photoreduction processes on $n-\mathrm{TiO}_{2}$ electrodes, Ber. Bunsenges, Phys. Chem., 84, 1040-1045 (1980).

[9] J. C. Pesant, P. Vennereau, Electrochemical behavior and photo-excitability of titanium oxides layer formed under low anodic polarisation conditions, J. Electroanal. Chem., 106, 103-113 (1980).

[10] E. Hristova, Lj. Arsov, B. Popov, R. White, Ellipsometric and Raman spectroscopic study of thermally formed films on titanium, J. Electrochem. Soc., 144 (7), 2318-2322 (1997).

[11] A. Prusi, Lj. Arsov, B. Haran, B. Popov, Anodic behavior of Ti in KOH Solutions, J. Electrochem. Soc., 149 (11), B491-B498 (2002).

[12] M. A. Butler, Localized photoelectrochemical measurements of passive films on titanium, J. Electrochem. Soc. 130 (12), 2358-2362 (1983).

[13] Lj. Arsov, C. Kormann, W. Plieth, Electrochemical synthesis and in situ Raman spectroscopy of thin films on titanium dioxide, J. Raman Spectrosc., 22, 573-575, (1991).

[14] T. Ohtsuka, T. Otsuki, The Influence of the growth rate on the semiconductive properties of titanium anodic oxide films, Corros. Sci., 40 (6), 951-958 (1998).

[15] A. Felske, W. Badawy, W. Plieth, The electrochemical and photoelectrochemical behavior of passivated $\mathrm{Ti}$ in ni- 
tric acid solutions, J. Electrochem. Soc., 137 (6), 1804 1809 (1990).

[16] A. Prusi, Lj. Arsov, The growth kinetics and optical properties of films formed under open circuit conditions on a titanium surface in potassium hydroxide solutions, Corros. Sci., 33 (1), 153-164 (1991).

[17] R. Sathyamoorthy, P. Sudhager, S. Chandramohan, K. Vijaykumar, Photoelectrical properties of crystalline titanium dioxide thin films after thermo-annealing, Cryst. Res. Technol, 42 (5), 498-503 (2007).

[18] J. Krysa, M. Zlámal, G. Waldner, Effect of oxidisable substrates on the photoelectrocatalytic properties of thermally grown and particulate $\mathrm{TiO}_{2}$ layers, J. Appl. Electrochem., 37, 1313-1319 (2007).

[19] I. Mintsouli, N. Philippidis, I. Poulios, S. Sotiropoulos, Photoelectrochemical characterization of thermal and particulate titanium dioxide electrodes, J. Appl. Electrochem. 36, 463-474 (2006).

[20] F. Di Quarto, M. Santamaria, P. Skeldon, G. Thompson, Photocurrent spectroscopy study of passive films on hafnium and hafnium-tungsten sputtered alloys, Electrochim. Acta, 48, 1143-1156 (2003).
[21] J. Sukamato, C. McMillan, W. Smyrl, Photoelectrochemical investigations of thin metal-oxide films; $\mathrm{TiO}_{2}$, $\mathrm{Al}_{2} \mathrm{O}_{3}$ and $\mathrm{HfO}_{2}$ on parent metals, Electrochim. Acta 38 (1), 15-27 (1993).

[22] I. Arsova, N. Hebestreit, N. Petrovska, A. Prusi, Lj. Arsov, Oxides formed on titanium by mechanical polishing, electrochemical polishing, etching, anodizing and thermal treatment, XIII Cong. of Chemis. and Technol. of Macedonia, ECH-9, 413-416 (2004).

[23] A. Hugot-Le Goff, Structure of very thin $\mathrm{TiO}_{2}$ films studied by Raman spectroscopy with interference enhancement, Thin Solid Films, 142, 193-197 (1986).

[24] M. Kozlowski, P. Tyler, W. Smyrl, Photoelectrochemical microscopy of oxide films on metals: $\mathrm{Ti} / \mathrm{TiO}_{2}$ interface, Surface Sci., 194, 505-530 (1988).

[25] Lj. Arsov, C. Kormann, W. Plieth, In situ Raman spectra of anodically formed titaniumdioxide layers in solutions of $\mathrm{H}_{2} \mathrm{SO}_{4}, \mathrm{KOH}$ and $\mathrm{HNO}_{3}$, J. Electrochem. Soc., 138 (10), 2964-2970 (1991).

[26] H. Vidersson, M. Elmgren, S. Lindquist, Photoelectrochemical etching of polycrystalline $\mathrm{TiO}_{2}$ thin film electrodes, Surface Sci. 191, 144-154 (1988). 